\title{
PENGKLASIFIKASIAN KARAKTERISTIK MAHASISWA BARU DALAM MEMILIH PROGRAM STUDI MENGGUNAKAN ANALISIS CLUSTER
}

\author{
Maxsi Ary \\ Program Studi Manajemen Informatika \\ Akademik Manajemen Informatika dan Komputer BSI Bandung \\ AMIK BSI Bandung \\ Jalan Sekolah Internasional No.1-6 Antapani, Bandung \\ maxsi.max@bsi.ac.id
}

\begin{abstract}
Object Clustering is one of the object mining process which aims to partition an existing object into one or more cluster objects based on their characteristics. Private Universities is one of the alternatives for the community colleges to meet increased demand for educational needs. The number of private colleges, especially in Bandung and generally in Indonesia is quite a lot. The number of colleges and universities means used to attract prospective students to be an interesting thing to study. As a reason for the intense competition in the search for new students, no doubt there are some ways that actually do not need to be done. Issues raised, namely classify new students of characteristics in selecting a course using cluster analysis. Data obtained from the questionnaire prospective new students in February 2014 Data processing using SPSS. The results using analysis SPSS aiming easier to describe the characteristics of each group of new students in choosing courses.
\end{abstract}

Keywords: Clustering, characteristics of students, courses, cluster analysis

\begin{abstract}
Abstrak - Pengelompokan Objek (object clustering) adalah salah satu proses dari objek mining yang bertujuan untuk mempartisi objek yang ada kedalam satu atau lebih cluster objek berdasarkan karakteristiknya. Perguruan tinggi swasta merupakan salah satu perguruan tinggi alternatif bagi masyarakat untuk menghadapi peningkatan permintaan terhadap kebutuhan pendidikan. Jumlah perguruan tinggi swasta khususnya di Bandung dan umumnya di Indonesia berjumlah cukup banyak. Jumlah perguruan tinggi dan cara yang digunakan perguruan tinggi untuk menarik minat calon mahasiswa menjadi hal yang menarik untuk dikaji. Sebagai alasan ketatnya persaingan dalam mencari calon mahasiswa baru, tidak dipungkiri terdapat beberapa cara yang dilakukan yang sebetulnya tidak perlu dilakukan. Persoalan yang dikemukakan yaitu mengklasifikasikan karakteristik mahasiawa baru dalam memilih program studi menggunakan analisis cluster. Data diperoleh dari hasil kuisioner calon mahasiswa baru pada bulan februari 2014. Pengolahan data menggunakan SPSS. Hasil analisis menggunakan SPSS tersebut bertujuan memudahkan untuk mendeskripsikan karakteristik masing-masing kelompok mahasiswa baru dalam memilih program studi.
\end{abstract}

Kata kunci: Clustering, Karakteristik Mahasiswa, Program Studi, Analisis Cluster. 


\section{PENDAHULUAN}

Terdapat beberapa teknik dalam statistik untuk menganalisis data. Salah satu caranya yaitu dengan menguji hipotesis nol (H0). Tujuan dari menganalisi data ini adalah

mendapatkan informasi yang berada dalam data tersebut. Informasi yang diperoleh ini digunakan untuk menyelesaikan suatu masalah. Permasalahan yang akan diselesaikan biasanya dinyatakan dalam hipotesis nol. Cara analisis data seperti ini disebut metode statistik hipotesis nol.

Untuk menganalisis data, diperlukan pula identifikasi pengukuran atau aturan pengukuran yang disebut skala pengukuran. Pengukuran menurut (Ghozali, 2011) merupakan suatu proses hal mana suatu angka atau simbol diletakkan atau properti suatu stimuli sesuai dengan aturan atau prosedur yang telah ditetapkan. Misalkan orang dapat digambarkan dari beberapa karakteristik seperti usia, pendidikan, agama, jenis kelamin, pendapatan. Skala pengukuran yang sesuai dapat digunakan untuk menunjukkan karakteristir ini. Menurut
(Steven, 1946) dalam buku (Ghozali, 2011) skala pengukuran dapat dikelompokkan menjadi empat yaitu, skala nominal, skala ordinal, skala interval, dan skala rasio.

Perguruan tinggi swasta merupakan salah satu perguruan tinggi alternatif bagi masyarakat untuk menghadapi peningkatan permintaan terhadap kebutuhan pendidikan. Jumlah perguruan tinggi swasta khususnya di Bandung dan umumnya di Indonesia berjumlah cukup banyak. Hal ini menyebabkan persaingan dalam hal menarik minat sebagai mahasiswa semakin ketat terutama dalam memberikan pelayanan kepada mahasiswa. Untuk menghadapi persaingan ini tidak sedikit keunggulankeunggulan perguruan tinggi swasta dikemukakan. Seperti keunggulan gelar kesarjanaan, kurikulum yang diberikan, sampai fasilitas yang dapat digunakan oleh mahasiswa (Sukandi, 2010).

Berikut data jumlah perguruan tinggi swasta yang didapat dari lingkungan Kopertis Wilayah IV Jawa Barat dan banten pada bulan Februari 2014.

Tabel 1

Jumlah Perguruan Tinggi Lingkup Kopertis IV Per Februari 2014

\begin{tabular}{|l|c|}
\hline \multicolumn{1}{|c|}{ Bentuk PTS } & Jumlah PTS \\
\hline Universitas & 20 \\
\hline Institut & 5 \\
\hline Sekolah Tinggi & 54 \\
\hline Akademi & 29 \\
\hline Politeknik & 13 \\
\hline Jumlah & $\mathbf{1 2 1}$ \\
\hline
\end{tabular}

Sumber: http://direktori.kopertis4.or.id/

Jumlah perguruan tinggi dan cara yang digunakan perguruan tinggi untuk menarik minat calon mahasiswa menjadi hal yang menarik untuk dikaji. Sebagai alasan ketatnya persaingan dalam mencari calon mahasiswa baru, tidak dipungkiri terdapat beberapa cara yang dilakukan yang sebetulnya tidak perlu dilakukan. Hasil dari cara tersebut tidak berdampak pada jumlah mahasiswa. Klasifikasi perilaku calon mahasiswa baru dalam memilih kampus dalam hal ini program studi/jurusan menjadi salah satu hal yang menarik untuk diteliti. Berbeda wilayah dan kebiasaan (life style), akan memberi dampak yang besar dalam hal memenangkan persaingan memperoleh jumlah mahasiswa. Klasifikasi gaya hidup calon mahasiswa baru dapat dipergunakan untuk mengukur profil psikografik mahasiswa baru itu sendiri. 
Analisis cluster bertujuan untuk mengelompokkan/mengklasifikasikan objek-objek berdasarkan karakteristik diantara objek-objek tersebut, sehingga dapat diketahui ciri khas dari tiap kelompok. Banyak objek yang diklasifikasikan dengan analisis cluster, diantaranya adalah produk (barang dan jasa), benda, manusia (responden konsumen) (Sitepu, Irmeilyana, \& Gultom, 2011) dalam buku (Supranto, Teknik Sampling Untuk Survei dan Eksperimen, Edisi Baru, 2000).

Dalam penulisan ini, persoalan yang dikemukakan yaitu mengklasifikasi perilaku calon mahasiswa baru dalam memilih program studi/jurusan. Di dalam penelitian ini menggunakan sampel $\mathrm{n}=$ 31 dan variabel pertanyaan 7 buah, jadi banyaknya elemen sampel cukup memadai (sampel yang dianjurkan adalah $4 \times 7=28$ atau $5 \times 7=35$ orang responden).

Data diperoleh dari hasil kuisioner calon mahasiswa baru yang datang ke kampus (Universitas BSI Bandung). Tujuan calon mahasiswa baru ini datang ke kampus bisa sekedar bertanya tentang program studi yang ada di kampus atau bahkan juga membeli formulir pendaftaran. Periode pembagian kuisioner dilakukan pada bulan Februari 2014, dengan mengambil responden sebanyak 31 calon mahasiswa baru dari berbagai sekolah menengah atas/kejuruan. Pengolahan data hasil kuisioner menggunakan SPSS (Statistical Package for Social Science).

Hasil analisis menggunakan SPSS tersebut dapat digunakan untuk mengklasifikasikan karakteristik perilaku mahasiswa baru dalam memilih program studi/jurusan.

\section{METODE PENELITIAN}

Pada bagian ini akan membahas aspek metodologi penelitian yang diterapkan dalam penelitian. Penulis akan memberikan gambaran rinci tentang metodologi penelitian. Ini mencakup jenis penelitian dan metode pengumpulan data.

\section{Jenis Penelitian}

Persoalan yang dikemukakan yaitu mengklasifikasi karakteristik mahasiswa baru dalam menentukan program studi. Analisis Cluster bertujuan untuk mengelompokkan objek-objek berdasarkan karakteristik diantara objekobjek itu, sehingga dapat diketahui ciri khas dari tiap kelompok.

\section{Metode Pengumpulan Data}

Untuk mendukung penelitian dilakukan pengumpulan data sebagai berikut:

1. Sumber Data

a. Data Primer

Hasil kuisioner calon mahasiswa baru yang sekedar bertanya atau mendaftar ke kampus Universitas BSI Bandung.

b. Data Sekunder

Data Sekunder merupakan data yang diperoleh secara tidak langsung, misalnya dari dokumentasi, literatur buku, jurnal, dan informasi lainnya yang ada hubungannya dengan masalah yang diteliti.

\section{Sampel Penelitian}

Sampel dari penelitian ini adalah calon mahasiswa baru yang sekedar bertanya atau mendaftar ke kampus Universitas BSI Bandung. Pemberian kuisioner dilakukan pada tanggal 6-15 Februari 2014. Jumlah responden berdasarkan kuisioner yang penulis buat berjumlah 31 responden.

\section{PEMBAHASAN}

Pada proses pengukuran ini dilakukan menggunakan analisis cluster dan analisis data menggunakan SPSS Inc 17.0. Berikut dilampirkan 7 pernyataan mengenai karakteristik mahasiswa baru dalam menentukan program studi. Data mengenai pernyataan perilaku diperoleh pada suatu skala 7 butir (1=sangat tidak setuju dan $7=$ sangat setuju): 
X1 : Saya lebih senang datang langsung ke kampus untuk memperoleh informasi jurusan/program studi daripada melalui media/perantara lain.

$\mathrm{X} 2$ : Saya selalu mengecek biaya pendaftaran dan biaya lainnya, walaupun

anggaran untuk kuliah relatif ada/kecil.

X3 : Iklan di Koran lebih jelas/ menarik daripada brosur.

X4 : Saya orang yang senang jika teman-teman satu jurusan/program studi banyak.

X5 : Saya berencana selain kuliah, bekerja/magang di instansi/kantor.

X6 : Saya berencana selain kuliah, melakukan bisnis kecil-kecilan/berwirausaha.

X7 : Saya memilih kampus ini karena terkenal di Bandung dan biaya terjangkau.

Data yang diperoleh dari sampel calon mahasiswa baru yang diuji sebanyak 31 orang sebagai responden. Waktu pelaksanaan pada bulan Februari 2014, bertepatan dengan jadwal penerimaan mahasiswa baru gelombang I (s.d. 1 April 2014). Langkah-langkah pengujian statistik adalah sebagai berikut:

1. Melakukan Standardisasi untuk mengantisipasi variabilitas satuan.

2. Melakukan analisis cluster dengan Hirarki

3. Melakukan analisis cluster dengan non-Hirarki

\section{Standardisasi Variabilitas Satuan}

Langkah pertama untuk diperhatikan untuk mengklasifikasikan menggunakan analisis cluster adalah standardisasi. Proses ini diperlukan apabila terdapat variabilitas satuan. Berikut adalah tabel (Tabel 1) hasil standardisasi untuk menyimpan sebagai nilai $\mathrm{Z}$ Score atau nilai variabel yang telah distandardisasi.

Tabel 1

Statistika Deskriptif Analisis Cluster

Descriptive Statistics

\begin{tabular}{|l|r|r|r|r|r|}
\hline & N & Minimum & Maximum & Mean & Std. Deviation \\
\hline x1 & 31 & 1 & 7 & 5.29 & 2.116 \\
x2 & 31 & 1 & 7 & 4.97 & 1.581 \\
x3 & 31 & 1 & 7 & 2.94 & 1.711 \\
x4 & 31 & 1 & 7 & 5.29 & 1.936 \\
x5 & 31 & 2 & 7 & 5.52 & 1.749 \\
x6 & 31 & 2 & 7 & 5.39 & 1.764 \\
x7 & 31 & 2 & 7 & 5.26 & 1.612 \\
Valid N (listwise) & 31 & & & & \\
\hline
\end{tabular}

\section{Analisis Cluster Metode Hirarki}

Berikut adalah hasil pengolahan data dengan SPSS.

Tabel 2

Proximities Jarak Euclidean

\begin{tabular}{cccccc}
\hline \multicolumn{6}{c}{ Case Processing Summary $^{\mathbf{a}}$} \\
\hline \multicolumn{5}{c}{ Cases } \\
\hline Valid & \multicolumn{4}{c}{ Missing } & \multicolumn{2}{c}{ Total } \\
\hline 31 & Percent & N & Percent & N & Percent \\
\hline
\end{tabular}

a. Squared Euclidean Distance used 
Tabel 2 menunjukkan bahwa semua data berjumlah 31 objek telah diproses dengan data hilang berjumlah 1 objek.

Tabel 3

Cluster Membership

\begin{tabular}{llll}
\hline Case & 4 Clusters & 3 Clusters & 2 \\
\hline $1: \mathrm{A}$ & 1 & 1 & 1 \\
\hline $2: \mathrm{B}$ & 2 & 2 & 2 \\
\hline $3: \mathrm{C}$ & 1 & 1 & 1 \\
\hline $4: \mathrm{D}$ & 1 & 1 & 1 \\
\hline $5: \mathrm{E}$ & 1 & 1 & 1 \\
\hline $6: \mathrm{F}$ & 1 & 1 & 1 \\
\hline $7: \mathrm{G}$ & 1 & 1 & 1 \\
\hline $8: \mathrm{H}$ & 1 & 1 & 1 \\
\hline $9: \mathrm{I}$ & 1 & 1 & 1 \\
\hline $10: \mathrm{J}$ & 1 & 1 & 1 \\
\hline $11: \mathrm{K}$ & 2 & 2 & 2 \\
\hline $12: \mathrm{L}$ & 1 & 1 & 1 \\
\hline $13: \mathrm{M}$ & 2 & 2 & 2 \\
\hline $14: \mathrm{N}$ & 1 & 1 & 1 \\
\hline $15: \mathrm{O}$ & 1 & 1 & 1 \\
\hline $16: \mathrm{P}$ & 2 & 2 & 2 \\
\hline $17: \mathrm{Q}$ & 2 & 2 & 2 \\
\hline $18: \mathrm{R}$ & 1 & 1 & 1 \\
\hline $19: \mathrm{S}$ & 1 & 1 & 1 \\
\hline $20: \mathrm{T}$ & 1 & 1 & 1 \\
\hline $21: \mathrm{U}$ & 1 & 1 & 1 \\
\hline $22: \mathrm{V}$ & 1 & 1 & 1 \\
\hline $23: \mathrm{W}$ & 1 & 1 & 1 \\
\hline $24: \mathrm{X}$ & 1 & 1 & 1 \\
\hline $25: \mathrm{Y}$ & 1 & 3 & 1 \\
\hline $26: \mathrm{Z}$ & 1 & 1 & 1 \\
\hline $27: \mathrm{AA}$ & 1 & 1 & 1 \\
\hline $28: \mathrm{AB}$ & 1 & 1 & 1 \\
\hline $29: \mathrm{AC}$ & 1 & 1 & 1 \\
\hline $30: \mathrm{AD}$ & 1 & 1 & 1 \\
\hline $31: \mathrm{AE}$ & 1 & 1 & \\
\hline & 1 & 1 & 1 \\
\hline
\end{tabular}

Proses Aglomerasi ini bersifat kompleks, khususnya perhitungan koefisien yang melibatkan sekian banyak objek dan terus bertambah. Proses aglomerasi pada akhirnya akan menyatukan semua objek menjadi satu cluster. Hanya saja dalam prosesnya dihasilkan beberapa cluster dengan 
masing-masing anggotanya, tergantung jumlah cluster yang dibentuk. Perincian jumlah cluster dengan anggotanya yang terbentuk dapat dilihat pada tabel 3.

Hasil pengolahan data pada tabel 3 terlihat bahwa objek terbagi menjadi 2 cluster, 3 cluster, dan 4 cluster. Apabila menggunakan 2 cluster, maka akan menjadi anggota cluster pertama terlihat pada kolom cluster 2 dengan simbol 1 . Sedangkan cluster kedua terlihat pada kolom cluster 2 dengan simbol 2.

\section{Analisis Cluster Metode non-Hirarki \\ Berikut hasil pengolahan data dengan SPSS.}

Tabel 4

Iteration History

Iteration History $^{\text {a }}$

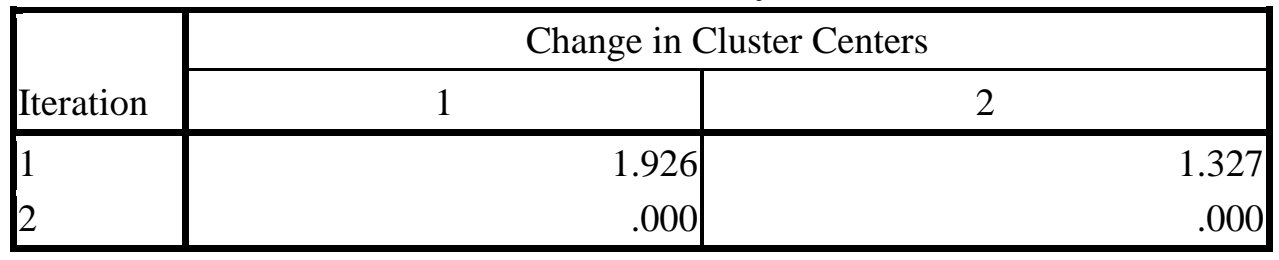

a. Convergence achieved due to no or small change in cluster centers. The maximum absolute coordinate change for any center is .000 . The current iteration is 2 . The minimum distance between initial centers is 7.114 .

Pada tabel 4 diketahui bahwa proses iterasi dilakukan sebanyak 2 kali. Proses tersebut dilakukan untuk mendapatkan cluster yang baik. Jarak minimum antar pusat cluster yang terjadi dari hasil iterasi adalah 7.114.

Tabel 5

Final Cluster

\begin{tabular}{lcr}
\hline \multicolumn{3}{c}{ Final Cluster Centers } \\
\hline & \multicolumn{2}{c}{ Cluster } \\
\hline & 1 & \multicolumn{1}{c}{2} \\
\hline Zscore $(\mathrm{x} 1)$ & .27861 & -1.16087 \\
\hline Zscore $(\mathrm{x} 2)$ & .24814 & -1.03391 \\
\hline Zscore $(\mathrm{x} 3)$ & $\mathbf{- . 1 9 6 0 2}$ & $\mathbf{. 8 1 6 7 7}$ \\
\hline Zscore $(\mathrm{x} 4)$ & .32533 & -1.35553 \\
\hline Zscore $(\mathrm{x} 5)$ & .29957 & -1.24822 \\
\hline Zscore $(\mathrm{x} 6)$ & .32477 & -1.35320 \\
\hline Zscore $(\mathrm{x} 7)$ & .36105 & -1.50438 \\
\hline
\end{tabular}

Hasil akhir dari proses clustering diperoleh pada tabel 5. Hasil output tabel 5 dapat dilihat bahwa data masih terkait dengan proses standardisasi yang mengacu pada Z-Score dengan ketentuan sebagai berikut:
1. Nilai Negatif (-) artinya data berada di bawah rata-rata total

2. Nilai Positif $(+)$ artinya data berada di atas rata-rata total

Dari tabel 5 Final Centers diperoleh hasil sebagai berikut:

\section{Cluster 1}

Dalam cluster 1 berisi variabel 3 memiliki nilai rendah, sedangkan variabel lainnya tinggi.

\section{Cluster 2}

Dalam cluster 2 berisi variabel 3 memiliki nilai tinggi, sedangkan variabel lainnya rendah.

Tahapan selanjutnya adalah melihat perbedaan variabel pada cluster yang terbentuk. Dapat dilihat pada tabel ANOVA (lihat lampiran) nilai $\mathrm{F}$ dan nilai probabilitas (sig) masing-masing variabel. Variabel 7 (Zscore (x7)) memilifi nilai $\mathrm{F}=37.009$ dan sig 0.000 . Menurut ketentuan besarnya nilai $\mathrm{F}$ semakin besar dan (sig < 0.05), maka semakin besar perbedaan variabel pada cluster yang terbentuk. Hasil tabel ANOVA menunjukkan variabel 7 adalah 
variabel yang paling menunjukkan adanya perbedaan diantara cluster lainnya.

Jumlah anggota masing-masing cluster yang terbentuk adalah sebagai berikut (tabel 6).

Tabel 6

Number Each Cluster

\begin{tabular}{llr}
\hline \multicolumn{3}{c}{$\begin{array}{c}\text { Number of Cases in each } \\
\text { Cluster }\end{array}$} \\
\hline Cluster & 1 & 25.000 \\
\cline { 2 - 3 } & 2 & 6.000 \\
\hline & Valid & 31.000 \\
\cline { 2 - 3 } & Missing & 1.000 \\
\hline
\end{tabular}

Jumlah cluster 1 memiliki anggota 25 responden, dan cluster 2 memiliki 6 responden. Sedangkan responden yang dianggap hilang berjumlah 1 responden.

\section{PENUTUP}

\section{Kesimpulan}

Dari hasil pengolahan data menggunakan SPSS Hasil analisis cluster diperoleh kesimpulan sebagai berikut:

1. Metode Hirarki dapat dikelompokkan menjadi dua, tiga, atau empat klasifikasi. Penulis mengambil dua cluster melihat nilai yang dihasilkan. Jumlah anggota cluster 1 berjumlah 26 responden, dan cluster 2 berjumlah 5 responden

2. Metode non-Hirarki dikelompokkan menjadi dua kelompok, yaitu Cluster 1 berisi variabel ke-3 memiliki nilai rendah, sedangkan variabel lainnya tinggi. Cluster 2 variabel ke-3 memiliki nilai tinggi, sedangkan variabel lainnya rendah. Jumlah anggota cluster 125 responden, dan cluster 2 berjumlah 6 responden

\section{Saran}

Variabel yang digunakan pada penelitian ini menggunakan 7 variabel dan dirasa perlu untuk ditambahkan kembali dengan variabel lainnya yang mendukung dalam pengelolaan kampus. Harapannya dapat memetakan hasil klasifikasi mahasiswa baru dalam menentukan program studi. Dari sisi jumlah responden penelitian ini menggunakan 31 responden mahasiswa baru, untuk penelitian selanjutnya dapat ditambah jumlah respondennya.

Penelitian ini merupakan kelanjutan dari penelitian sebelumnya mengenai identifikasi perilaku mahasiswa baru dalam menentukan program studi menggunakan analisis factor. Untuk mengambil kesimpulan secara utuh mengenai identifikasi variabel dan klasifikasi objek, maka perlu diperhatikan lebih seksama mengenai hal tersebut. (Ary, 2014)

\section{REFERENSI}

Ary, Maxsi. (2014). Identifikasi Perilaku Calon Mahasiswa Baru dalam Memilih Program Studi Menggunakan Analisis Faktor. Paradigma Jurnal Komputer dan Informatika Akademi Bina Sarana Informatika, 35-45.

Damanhuri, D. S. (n.d.). Dunia Esai. Retrieved September 12, 2012, from Kumpulan esai berbahasa Indonesia:

http://www.duniaesai.com/index .php?option=com_content\&vie $\mathrm{w}=\operatorname{article} \& \mathrm{id}=108$ : $\mathrm{sdm}-$ indonesia-dalam-persainganglobal\&catid=37: ekonomi\&Ite mid=93

Ghozali, I. (2011). Aplikasi Analisis Multivariate dengan Program IBM SPSS 19. Semarang: Badan Penerbit Universitas Diponegoro.

Gujarati, D. (2003). Basic Econometrics. New York: Mc-Grawhill.

Hadianto, B., \& Wijaya, M. V. (Desember 2010). Prediksi Kebijakan Utang, Profitabilitas, 
likuiditas, Ukuran, dan Status

Perusahaan Terhadap

Kemungkinan Penentuan

Peringkat Obligasi: Studi

Empirik pada Perusahaan yang

Menerbitkan Obligasi di Bursa

Efek Indonesia. Jurnal

Manajemen Teori dan Terapan,

Tahun 3, No.3.

Sitepu, R., Irmeilyana, \& Gultom, B. (2011). Analisis Cluster terhadap Tingkat Pencemaran Udara pada Sektor Industri di Sumatera Selatan. Jurnal Penelitian Sains, 11-17.

Steven, S. (1946). On The Theory of Scales of Measurement. Science, 103.

Sukandi, P. (2010). Hubungan Antara Fasilitas Kampus Terhadap Kepuasan Mahasiswa dalam Menghadapi Daya Saing Jasa Pendidikan (Studi Kasus: Mahasiswa Fakultas Bisnis dan Manajemen Universitas Widyatama). The 4th PPM National Confrence on Management Research. Jakarta.

Supranto, J. (2000). Teknik Sampling Untuk Survei dan Eksperimen, Edisi Baru. Jakarta: PT. Rineka Cipta.

Supranto, J. (2010). Analisis Multivariat : Arti \& Interpretasi. Jakarta: Rineka Cipta.

Tabachnick, B. (1996). Using Multivariate Statistics. New York: Harper Collin. 